\title{
C-C Motif Chemokine 19
}

National Cancer Institute

\section{Source}

National Cancer Institute. C-C Motif Chemokine 19. NCI Thesaurus. Code C28733.

C-C motif chemokine 19 (98 aa, $\sim 11 \mathrm{kDa}$ ) is encoded by the human CCL19 gene. This protein is involved in lymphocyte recirculation and homing. 